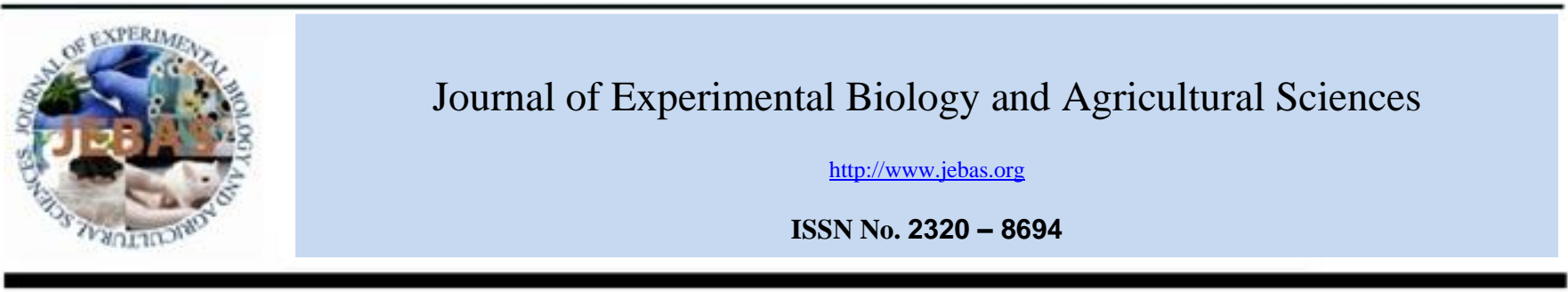

\title{
DEVELOPMENT OF COLORED MANGO (Mangifera indica L.) HYBRIDS THROUGH HALF-DIALLEL CROSSING
}

\author{
B. R. Jana
}

ICAR-RCER, Research Centre Ranchi, Namkum, Jahrkhand, India-834010

Received - January 10, 2017; Revision - March 12, 2017; Accepted - April 14, 2017

Available Online - May 12, 2017

DOI: http://dx.doi.org/10.18006/2017.5(2).220.224

KEYWORDS
Mango
Colored Hybrid
Bearing Habit
TSS
Yield

\begin{abstract}
Mango cultivars like Langra, Dashehai and Chausa are famous for their unique test and high TSS content. Due to their size and bearing potential, these verities are not only popular in Jharkhand but also in demand throughout the India. To mitigate the growing demand of colored mango variety in local as well as national market, a varietal improvement program has been conducted at ICAR-RCER, Research Centre, Ranchi, India. During this study, mango cultivars Langra, Dashehai and Chausa have been used as female plant while pollen grain of Swarnarekhan, Kesar and Vanraj were used as male parent in diallel crosses. Results of study revealed that Hybrids obtained by the crossing of Langra $x$ Vanraj (Hybrid 1) and Langra $x$ Kesar (Hybrid -2) are superior in term of their fruit tree character, bearing habit and fruit quality. Among various obtained Hybrids, Hybrid -2 (Langra x Kesar) have highest TSS $\left(20.5^{\circ} \mathrm{B}\right)$ and total sugar content $(12.37 \%)$ with yellow color, this was followed by Hybrid $-\mathrm{I}\left(19.5^{\circ} \mathrm{B}\right)$ and Hybrid-3 $\left(11.5^{\circ} \mathrm{B}\right)$. In terms of regular bearing, Hybrid -1 was the most promising one and it was followed by the Hybrid-3 (Chausa x Vanraj). Further, with respect to yield potential, Hybrid -2 showed superiority over the rest two Hybrids and 7 year old plant gave $12.5 \mathrm{~kg}$ fruit/year.
\end{abstract}

\section{* Corresponding author \\ E-mail: brjana.ars@gmail.com (B. R. Jana)}

Peer review under responsibility of Journal of Experimental Biology and Agricultural Sciences.

Production and Hosting by Horizon Publisher India [HPI] (http://www.horizonpublisherindia.in/).

All rights reserved
All the article published by Journal of Experimental Biology and Agricultural Sciences is licensed under a Creative Commons Attribution-NonCommercial 4.0 International License Based on a work at www.jebas.org.

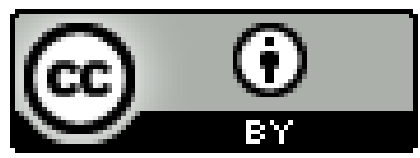




\section{Introduction}

Mango (Mangifera indica L.), belongs to the family Anacardiaceae and is well known for its high TSS, attractive color, size and Vitamin A content. It has been associated with human culture since 4000 years (Condole, 1984) and it is mainly grown in tropical and subtropical areas of the world as well as in India. According to Popenoe (1920) it has been originated in Eastern India stretching from Assam to Burma and to some extent in Malay region. Further, Mukherjee (1997) mentioned that South East Asia is the primary centre of origin for the mango tree and maximum diversity of this tree was reported from this region only. India has higher genetic diversity of mango; as per the report of Morton (1987) more than 500 wild mango varieties are available in India. Being a largest mango producer, India is now producing 18.43 million tons mango from an area of 2.51 million hectare and maintaining the productivity level of $7.3 \mathrm{t} / \mathrm{ha}$ (NHB database, 2014).

Flowering time and type of flower influenced the mango production and its quality. In this context, Srivastava et al., (1987) categorized Swarnarekha, Vanraj, Langra, Kesar and Fernandin as early flowering mango cultivars under Indian condition. Avilan et al. (1998) studied flower diversity in twenty one mango cultivars of Venezuela and reported that flower number per panicle varies from 601 (cv. Haden) to 4,859 (cv. Irwin). Moreover it was also reported that percentage of female flower varies from cultivars to cultivars. Similarly, Narayanaswamy \& Thimmaraju (1990) conducted a study on cultivars Langra and reported that this cultivar have very high percentage $(61.5 \%)$ of hermaphrodite flower.

Like flowering time, fruit color is also an important parameter, which significantly influences the mango trading among consumers. So far, inheritance pattern of fruits color have not been studied well but available research reports revealed that it has been governed by polygenes and different color fruit was observed due different gene combinations (Iyer, 1991). In contrary to this Sharma (1987) and Sharma \& Majumder (1989) stated that red color is dominant over green. Hence, when a "Janardan Pasand" (coloured variety) was crossed with normal green cultivar a wide array of colors were observed in the progeny (Iyer \& Subramanyam, 1979).

Fruits are climacteric in nature which ripened after harvest; therefore, a post harvest handling of fruits also determines the taste and quality (Mitra \& Baldwin, 1997). In Jharkhand, prominent mango cultivars were Langra, Dashehari and Chausa. Due to sub-humid condition of Ranchi these varieties remained yellowish green even after maturity. Similarly, Kaur et al. (2014) reported that climatic condition of Punjab also enhanced the development of light yellow colors on ripening. A mango breeding program was conducted at the Central Institute for Subtropical Horticulture, Lucknow (1992), to obtained regular bearing high yielding colored cultivars for domestic as well as export markets (Negi et al., 2000). In this program, a Hybrid was developed by crossing 'Dashehari' $\mathrm{X}$
'Chausa' allias, this Hybrid 'CISH-M-2' had average fruit weight of $220 \mathrm{~g}$ and having TSS of $23.00{ }^{\circ} \mathrm{B}$. The importance of fruit color in the economy of fruit was well reported. Therefore, the aim of present study was to incorporate the brilliant colors of Vanraj, Kesar and Swarnarekha into commercial cultivars Langra, Dashehari and Chausa by this Hybridization program.

\section{Materials and Methods}

This Hybridization study was conducted at ICAR Research Complex for Eastern Region, Research Centre, Ranchi during 2005 and 2006 and results were evaluated in 2012-13 when forth fruiting stage occurred on tree. Study area was situated $620 \mathrm{~m}$ above mean sea level (msl) at $23^{\circ} 25^{\prime} \mathrm{N}$ latitude and $85^{\circ}$ $20^{\prime}$ East longitude experiencing an average annual rainfall of $110-140 \mathrm{~cm}$. Study area soil is acidic and $\mathrm{p}^{\mathrm{H}}$ range from 5.06.5, which is ideal mango cultivation. Total 3780 flowers were pollinated during 2005-06 by following conventional breeding half diallel cross matting design. Female cultivars used in this breeding program were Langra, Dashehai and Chausa whereas the pollen grains were collected from cultivars Vanraj, Swarnarekhan and Kesar. Hybridization program carried out at the first farm of the Research Centre, Ranchi during full bloom period (Feb-March).

Pollen were collected from unopened flower of desired parents before $8.00 \mathrm{AM}$ morning and kept in petridish having moist blotting paper. Then lid of petridish was closed and kept in sunlight for 30 minutes for releasing pollen grain from the anthers. After emasculation of hermaphrodite flowers from the apical portion of panicle, pollination process was carried out with the help of forceps having ruptured anthers through brushing up of the stigma of the emasculated styles. Tree characteristics were recorded by the standard method and TSS of mango fruits was determined by ATAGO digital refractometer whereas total sugar was determined by Lane and Eynon methods (Ranganna, 1996). Data from fruit physicochemical characters was statistically analyzed by adopting Completely Randomized Design with three replications from a tree. Color of the Hybrids as well as parent mango cultivars were determined by the Royal Horticulture Society color chart, which was recommended by UPOV (2006).

\section{Results and Discussion}

During the Hybridization, total 3780 flower were cross pollinated but the success rate of fruit set was very less and among these 3780 cross pollinated mango trees only 15 can reached up to the Hybrid fruit development. From these 15 Hybrid fruits, only 11 can establish as segregated plants in F1 generation for the final evaluation of tree and fruit characteristics. Though initial fruit set was high for both the years but final fruit set was reduce to $0.35 \%$ and $0.38 \%$ in the year 2005 and 2006, respectively(Fig. 5). Among the 11 Hybrids, Langra x Vanraj (Hybrid 1) and Langra x Kesar (Hybrid 2) were important in term of yield, bearing habit and their attractive fruit colors (Table1\& 2). Fruit characteristics of 
various cultivars were represented in table 3 . Plant obtained by the crossing of Langra $x$ Vanraj (Hybrid 1) are medium in size and bloomed early in the month of February, fruits have attractive color with red blush on shoulder (Fig. 1). It had very large and deep pink colored panicles (Table 1, Fig. 2) with $45.24 \%$ hermaphrodite flowers. This result was corroborated the findings of Narayanswamy \& Thimmaraju (1990). Further, second promising cross Langra x Kesar (Hybrid 2) had attractive golden yellow colored fruit (Fig. 3) where as the crossing between Chausa $\mathrm{x}$ Vanraj were identified as Hybrid 3 and gave greenish yellow color fruit and dwarf plant (Fig 4). The Hybrids from Langra bear fruits in 2nd week of February which is reported earliest in Jharkhand condition. This finding was similar to that of Srivastava et al. (1987). Among various texted Hybrid combinations, least fruit set was observed in Hybrid 4 (Dashehari x Swarnarekha). With regard to fruit quality concerned, maximum fruit weight $(262.75 \mathrm{~g}$ ) was reported from the Hybrid 3 and it was followed by Hybrid -1 and Hybrid -2 those exhibited average fruit weights of 230.56 and $250.12 \mathrm{~g}$, respectively. In case of fruit TSS highest TSS content $\left(20.5^{\circ} \mathrm{B}\right)$ was reported from the Hybrid 2 while it was lowest $\left(11.5^{\circ} \mathrm{B}\right)$ in Hybrid 3. Like TSS, highest sugar content $(12.37 \%)$ was reported from the Hybrid 2 which considered as one of the superior F1 Hybrids in the breeding program.

Results suggested that red color of Vanraj was successfully transfer to Langra variety in Hybrid -1 , which enabled us to explain that fruit color is a polygenic character and genes act in a group that segregated together (Sharma, 1987) or are separated with different gene combinations. Similar opinion was given by Iyer \& Subramanyam (1979) and Iyer (1991). On the contrary Sharma (1987) stated that red color gene is dominant over recessive (green) which was further confirmed by Sharma \& Majumder (1989). In present study, most of the segregated population was alternate bearer except Hybrid 1. On the other hand, Hybrid 2 found excellent in all studied characteristics but it has some alternate bearer. Further, Hybrid 3 was also found excellent in its dwarf stature while Hybrid-4 was recognized for its profuse flowering. All 11 plants, particularly above mentioned 4 Hybrid cultivars have been maintaining in Ranchi Centre for their plant variety registration (Table-4).

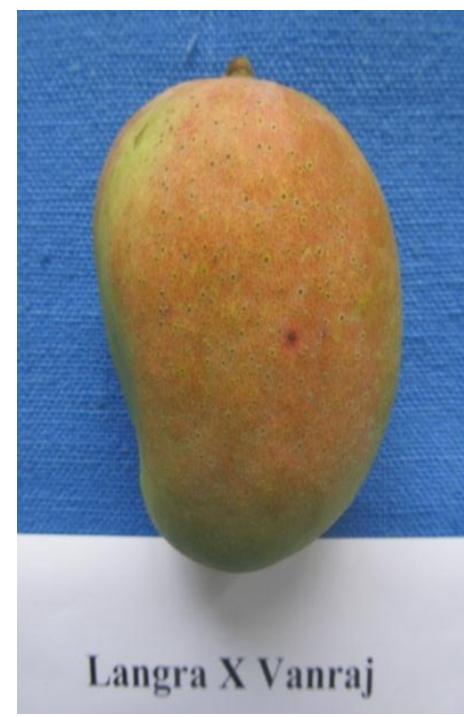

Figure 1 Fruit of Hybrid -1 (Chausa x Vanraj)

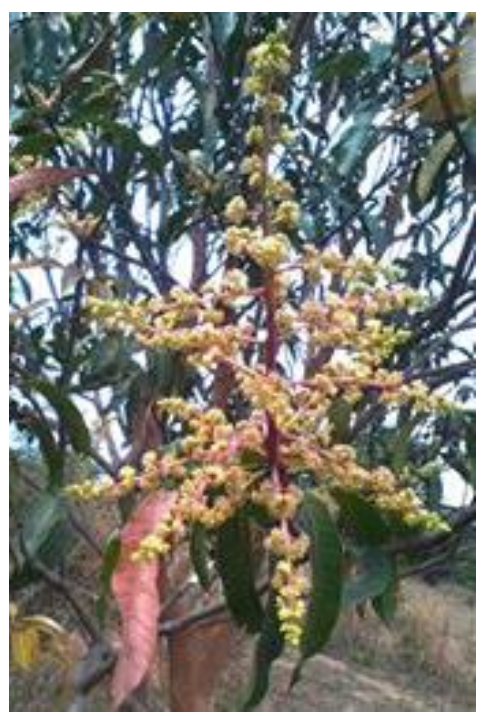

Figure 2 Inflorescence of Hybrid -1 (Langra x Vanraj)

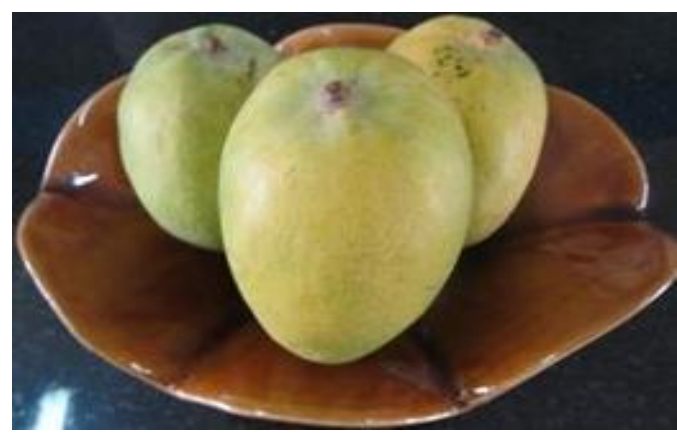

Figure 4 Fruits of Hybrid -3 (Chausa x Vanraj)

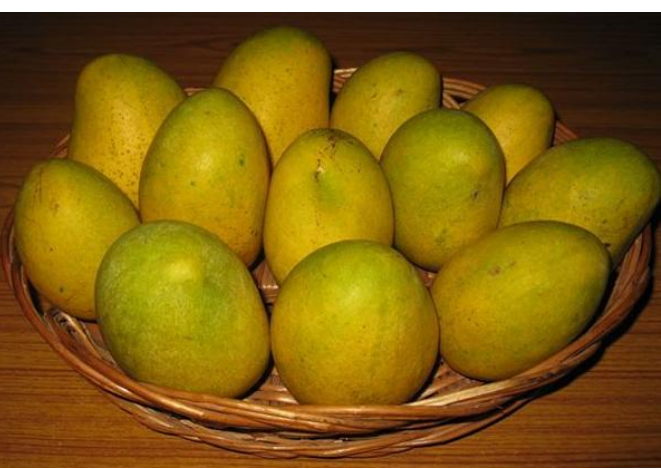

Figure 3 Fruits of Hybrid-2 (Langra X Kesar)

Journal of Experimental Biology and Agricultural Sciences

http://www.jebas.org 
Development of Colored Mango (Mangifera indica L.) Hybrids through Half-Diallel Crossing

Table 1 Physical characteristics of F1 population of mango during 2012-13

\begin{tabular}{|lcccc|}
\hline Cross combinations & Tree type & Inflorescence & Bearing Habit & Hermaphodite flower $\%$ \\
\hline Langra x Vanraj [ Hybrid-1] & Medium erect & Pink coloured & Regular & 45.24 \\
\hline Langra x Vanraj [Off Type-1] & Medium erect & Yellow & Alternate & 25.62 \\
\hline Langra x Kesar [ Off Type-2] & Medium erect & Yellow & Alternate & 23.89 \\
\hline Langra x Kesar [ Hybrid-2] & Medium spreading & Golden Yellow & Alternate & 54.65 \\
\hline Langra x Swarnarekha [ Off Type-3] & Wild type & Yellow & Alternate & 24.96 \\
\hline Langra x Swarnarekha [ Off type-4] & Wild type & Yellow & Alternate & 18.75 \\
\hline Chausa x Vanraj [ Hybrid-3] & Medium spreading & Yellow & Alternate & 19.67 \\
\hline Chausa x Swarnarekha [ Off type-5] & Dwarf & Redish yellow & Alternate & 22.82 \\
\hline Chausa x Swarnarekha [ Off type-6] & Medium Spreading & Yellow & Alternate & 16.25 \\
\hline Dashehari x Kesar [Off type-7 ] & Dwarf & Deep Yellow & Alternate & 19.64 \\
\hline Dashehari x Swarnarekha [ Hybrid -4] & Dwarf & Greenish Yellow & Alternate & 35.32 \\
\hline [CRD] CD at 5\% & -- & --- & --- & 5.86 \\
\hline
\end{tabular}

Table 2 Two years pooled data regarding fruit characteristics as affected by alternate bearing (2012-13).

\begin{tabular}{|lcccc|}
\hline Cross combinations & Fruit weight $(\mathbf{g})$ & TSS $\left({ }^{\mathbf{0}} \mathbf{B}\right)$ & Total Sugar $(\%)$ & Plant yield (Kg/plant ) \\
\hline Langra x Vanraj [ Hybrid-1 ] & 230.56 & 19.5 & 11.42 & 10.07 \\
\hline Langra x Vanraj [Off Type-1] & 200.45 & 16.3 & 9.87 & 4.25 \\
\hline Langra x Kesar [ Off Type-2] & 212.85 & 15.7 & 8.88 & 5.63 \\
\hline Langra x Kesar [ Hybrid-2] & 250.12 & 20.5 & 12.37 & 12.50 \\
\hline Langra x Swarnarekha [ Off Type-3] & 152.00 & 14.8 & 8.24 & 5.97 \\
\hline Langra x Swarnarekha [ Off type-4] & 174.64 & 12.8 & 7.99 & 4.89 \\
\hline Chausa x Vanraj [ Hybrid-3] & 140.67 & 11.5 & 8.88 & 8.72 \\
\hline Chausa x Swarnarekha [ Off type-5] & 262.75 & 11.5 & 7.45 & 7.42 \\
\hline Chausa x Swarnarekha [ Off type-6] & 128.45 & 11.5 & 7.41 & 7.69 \\
\hline Dashehari x Kesar [Off type -7] & 205.86 & 10.31 & 6.65 & 6.83 \\
\hline Dashehari x Swarnarekha [ Hybrid -4] & 188.52 & 12.25 & 7.58 & 2.61 \\
\hline [CRD] CD at 5\% & 34.08 & 2.49 & 1.82 & \\
\hline
\end{tabular}

Table 3 Quality characteristics of female parents used in hybridization program.

\begin{tabular}{|l|c|c|c|c|}
\hline Genetic resources & Colour of fruits & Organoleptic test & Pulp & TSS $\left({ }^{\circ}\right.$ Brix $)$ \\
\hline Dashehari & Yellowish Green 146A & 7.0 & 78.06 & 18.40 \\
\hline Langra & Yellowish Green 145A & 7.1 & 79.28 & 21.02 \\
\hline Chausa & Yellowish Green 145B & 8.3 & 85.78 & 23.08 \\
\hline
\end{tabular}

Table 4 Quality characteristics of newly hybrid cultivars (F1 Hybrids) developed through hybridization program

\begin{tabular}{|c|c|c|c|c|}
\hline Hybrids & Colour of Hybrids & Organoleptic test (Score 10) & Pulp (\%) & TSS ( ${ }^{\circ}$ Brix $)$ \\
\hline Hybrid-1 & Yellowish Green 146A Redish Blush: & 7.2 & 77.98 & 19.5 \\
\hline Hybrid-2 & Golden Yellow 154A & 8.1 & 82.25 & 20.5 \\
\hline Hybrid-3 & Yellowish Green 145B & 6.7 & 76.05 & 11.5 \\
\hline Hybrid-4 & Light Green N 144B & 6.3 & 74.42 & 12.25 \\
\hline
\end{tabular}

Journal of Experimental Biology and Agricultural Sciences

http://www.jebas.org 


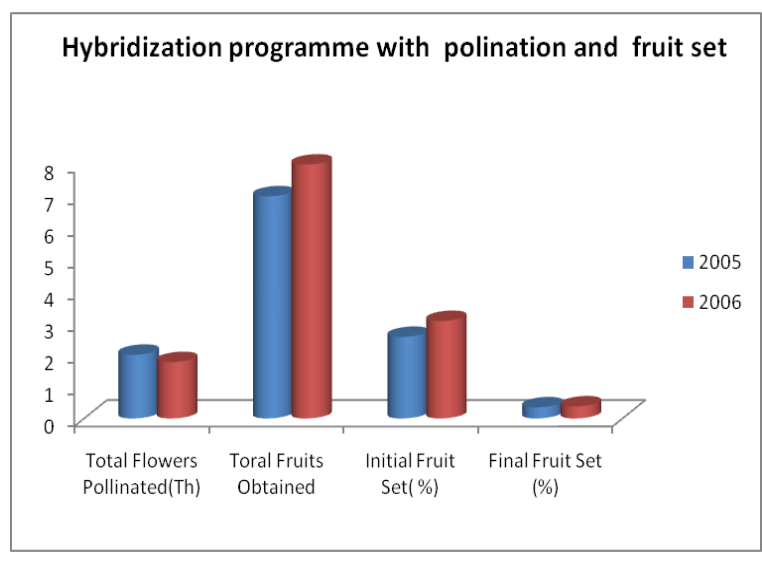

Figure 5 Pollination and fruit set and number of Hybrid fruits obtained during 2005-06.

\section{Conflict of interest}

Authors would hereby like to declare that there is no conflict of interests that could possibly arise.

\section{References}

Avilan L, Rodríguez M, Ruiz J (1998) El Cultivo del Manguero en Venezuela. FONAIAP Edition, Maracay, Venezuela, Pp. 59-92.

Condole AD (1984) Origin of cultivated plants. Vegal Paul Trench and Co. London. pp. 1-67.

Iyer CPA (1991) Recent advances in varietal improvement in mango. Acta Horticulturae 291: 109-132. DOI: https://doi.org/10.17660/ActaHortic.1991.291.14.

Iyer CPA, Subramanyam MD (1979) Improvement of mango by selection and hybridisation. In: Annual Report of the Indian Institute for Horticultural Research. Indian Institute for Horticultural Research, Bangalore, Pp. 11.

Kaur M, Bal JS, Sharma LK, Bali SK (2014) An evaluation of mango (Mangifera indica L.) germplasm for future breeding programme. African Journal of Agricultural Research 9:15301538. DOI: 10.5897/AJAR2014.8583.
Mitra SK, Baldwin EA (1997) Mango. In: Mitra S (Ed.), Postharvest Physiology and Storage of Tropical and Subtropical Fruits, CAB International, Wallingford Pp. 85-122.

Morton J (1987) Fruits of Warm Climates. J.F. Morton, Miami, Chapter Mango Mangifera indica $\mathrm{L}$.

Mukherjee SK (1997) Introduction botany and importance. In: Litz RE (Ed.) The mango: botany, production and uses. CAB International, Wallingford, U.K. Pp. 1-19. DOI: $10.1079 / 9781845934897.0001$

Narayanaswamy P, Thimmaraju KR (1990) A note on the sex ratio of North Indian cultivars of mango grown under South Indian conditions. Current Research $22: 48-50$.

Negi SS, Rajan S, Kumar R (2000) Developping new mango through hybridization. Acta Horticulture 509:159-170. DOI:10.17660/Acta Hort.2000.509.15

NHB (2014). Indian Horticulture Database. Gurgoan, India. http://www.nhb.com.

Popenoe FW (1920) The mango in southern California. Journal of Economic Botany. 1:153-200.

Ranganna S (1996) Manual of analysis of fruits and vegetables product. Tata McGrawHill Publishing Co.Ltd. New Delhi. pp29-31.

Sharma DK (1987) Mango Breeding. Acta Horticulturae 196: 61-67

Sharma DK, Majumder PK (1989) Inheritance in mango. Acta Horticulture 231: 106-111.

Shrivastava SS, Asati KP, Patel MP, Tiwary BL, Bhadauria US (1987) Evaluation of mangovarieties in Madhya Pardesh. Indian Journal of Horticulture 44: 197-201

UPOV (2006) Color names of RHS colour chart: International union for the production of new varieties of plants,Geneva.TGP/14/1 Draft -1. Section 2(3) (2) Annexure 1, Page-12. 